\title{
Hybrid Urban Identity-The Case of Rotterdam
}

\section{Peter Nientied}

Polis University, Tirana \& Associate, Institute for Housing and Urban Development Studies, Erasmus University Rotterdam, Rotterdam, The Netherlands

Email: nientied1@chello.nl

How to cite this paper: Nientied, P. (2018). Hybrid Urban Identity-The Case of Rotterdam. Current Urban Studies, 6, 152-173.

https://doi.org/10.4236/cus.2018.61008

Received: February 18, 2018

Accepted: March 24, 2018

Published: March 27, 2018

Copyright (C) 2018 by author and Scientific Research Publishing Inc. This work is licensed under the Creative Commons Attribution International License (CC BY 4.0).

http://creativecommons.org/licenses/by/4.0/

\begin{abstract}
This essay aims to investigate the development of Rotterdam's urban identity. It is a case study, with a theoretical reflection on the concept of urban identity. Rotterdam is a post-industrial port city in a process of physical, social and economic transformations. A narrative is developed on urban identity along the frame of a research on Rotterdam's identity 15 years ago that identified aspects of what was "typical Rotterdam". It is clarified that Rotterdam's identity is changing. The physical reconstruction period is finished, the port facilities have moved to the shore and a much more diverse population and culture, are factors influencing Rotterdam's identity. And values, such as the feminization of society, start to play a role. The conclusion is that Rotterdam's identity becomes more hybrid.
\end{abstract}

\section{Keywords}

Urban Identity, Place Attachment, Rotterdam, Urban Development

\section{Introduction}

How citizens think and feel about a city differs, because each citizen has a different subjective attachment to the city. Perceptions of a city's identity are equally varied. In the Netherlands, Rotterdam's identity has been a collective story of a working class and entrepreneurial port city that was reconstructed after it was severely damaged during the Second World War (WWII). Rotterdam has been known as a harbor city, with an open, no-nonsense, "roll up the sleeves" working culture. However, urban identity, as it is pictured in this fashion, is becoming a partial and superficial impression. The city has changed over the last decades: port facilities have moved out of the city towards the sea, the city's economy has been transformed, the composition of the population has become very diverse and the post war reconstruction has been completed. What remains are the stories and the images with their roots in the post WWII recon- 
struction period. This reconstruction identity persists, is kept alive, but is losing significance as the identity of the city. New stories on Rotterdam have different roots; they mainly come from younger generations and from newcomer households in the city-households from minorities with an international migrant background.

In this essay, the aim is to discuss the evolution of Rotterdam's identity. The "traditional Post WWII identity" will be labelled as the reconstruction identity and it will be argued that a new, more inarticulate identity develops, that will be labelled as hybrid identity.

We start the story of Rotterdam's identity in 1945, and therefore skip a lot of history. The history of Rotterdam has been well documented, the recent evolution of its identity much less. We first examine the concept of urban identity. Then attention turns to a concise reading of post-WWII developments of Rotterdam and subsequently to an interpretation of Rotterdam's identity. This we will do along the lines of a text on urban identity of Fortuin and Van der Graaf (2006), based on research done in 2002-3, about 15 years ago. We will also review how local government has been active in developing a story of the city and developed a logic for a new branding approach, and we will briefly review three recent programs. In a concluding section, we will draw conclusions about Rotterdam's evolving hybrid identity, and submit a final reflection on the concept of urban identity.

\section{The Concept of Urban Identity}

In a globalizing world, attention to the topic of urban identity has grown (Scannel \& Gifford, 2010; Lewicka, 2011; Evans et al., 2011; Čamprag, 2014; Sandholz, 2017). From a built environment perspective, Adams (2011) refers to homogenization and localization. And as Bell \& de-Shalit (2011: p. xii) suggest; "More and more people experience a growing sense of cosmopolitanism, but they also want to feel unique. Cities, we think, allow for a combination of both cosmopolitanism and a sense of community rooted in particularity". This particularity, the distinctiveness, is what urban identity is about. Urban identity is defined in various manner which all pertain to urban identity as the concept of "distinctiveness" (Cheshmehzangi, 2015). Notions used include place identity, sense of place, image of a place, sense of place, ethos (Bell \& de-Shalit, 2011), city personality (Landry \& Murray, 2017), place character (Berger, 2016), and spirituality of place (Singer, ed., 2010). There are many terms indeed to depict urban identity.

A distinction can be drawn between the identity of the place itself and the subjective identity (Lalli, 1992; Sandholz, 2017). In this fashion, urban identity can be described 1) as a feature of the city based on a collective attribution; each city holds its own urban identity based on its main features and constructed by a collective attribution, and 2) as the self-identification of the person with the city-the built environment with its connotative meanings-influences a person's identity. There is no clarity in literature on how place attachment and place 
identity are related, sometimes they are used interchangeably (Lalli, 1992), whereas other studies see place attachment as a part of place (urban) identity (Lewicka, 2008; Sandholz, 2017). Rollero and De Piccolo (2010) conclude that the relationship between people and places is characterized by affective and cognitive dimensions, defined, respectively, as place attachment and identification. Urban identity pertains to collective identity. Cheshmehzangi (2015) identifies different levels of urban identity, from global (the Eiffel Tower is an identity of Paris to the whole world), to the urban setting (like in urban branding), the place itself and the personal perspective. He suggests that "cultural identity" is the basis of distinctiveness determining qualities that exist only in a particular place, in which the meaning of a place is very essential to individuals' socio-behavioral attributes to the happenings in a place (ibid., 403).

Place, like a city, is conceived as a meaningful location, it is an entity that has a social dimension and a very real physical basis (Lewicka, 2008). Place identity is often studied as place attachment. People feel attached to a city because of different motives or sentiments. Some have close social ties in their neighborhood or generational rootedness, others may feel attached to the physical assets of places, such as a physically stimulating environment, or architectural attractiveness. Also, economic aspects play a role, such as work, having local clients or an own home. A traditional viewpoint on what makes a person a part of a community and which factors contribute to full identification with place, like Hay (1998) gives, suggest that there are different gradations of "being insider"; from being an outsider, to superficial, partial, etc., to a full sense of place when one has been raised in a place and has families living in a place for generations (cf. Lewicka, 2011). This viewpoint assumes that there is order, that there is something like a "true" attachment of place-a place as bounded, unique, with a clear identity of its own, having so-called genius loci (the character of a place in itself). An opposing viewpoint is that place attachment and identification can be regarded as processes, which develop in line with a range of factors. For newcomers to a city, place attachment may develop independently of residence time, and the nature of newcomers' attachment may differ from the attachment of older residents. There is not one "genius loci", there are as many as there are residents. Attachment according to social/ethnic group has not been researched in large cities. Landry (2017: p. 33) gives a modern twist to this debate and discusses "old and new nomads", to ask the question "Who is more of a citizen, the committed outsider or the unconcerned insider?".

The concept of urban identity is rather hard to depict. It refers to the collective identity of inhabitants of a city. It is fragmented and contested rather than unified, reflecting different social groups and interests (Mah, 2014). There is no adequate theory of urban identity (Devine-Wright \& Clayton, 2010; Lewicka, 2011; Hauge, 2007; Williams, 2014; Karpovets, 2014). Urban identity is a dynamic process, it is a work in permanent progress so to speak, and this process focuses on distinctiveness or uniqueness. There are no measures for urban iden- 
tity - and there cannot be one accepted portrait of a city's identity. Urban identity is sometimes seen as the physical icons but buildings (like the Eiffel Tower) by themselves have no identity-identity is a quality in the minds of people. Voicing one's own identity-at individual level—is not easy, and explaining how place is related to this identity, is hard. At a collective urban level, urban identity research implies deciphering the collective sense citizens make of their city's identity. But people do not think and communicate in terms of urban identity-they have thoughts, memories, feelings (place attachment for example), tell stories and the sum of all this related to the city, in social interaction, contributes to urban identity formation. How interaction between collective (urban) identity and individual identity exactly works, is hard to unravel. Filep et al. (2014) argue that narratives are the means of interaction and the key is to discover which stories are being told (and which are not) and to understand how those stories provide the context for socio-cultural identities. When we look at empirical work on urban identity at city level, urban identity as collective attribution, we see often impressionistic accounts of cities (Bell \& de-Shalit, 2011; Landry \& Murray, 2017; Singer, ed., 2010; Solesbury, 2013), while academic studies such as Berger (2016) and Van den Berg (2017) are rather rare.

Much academic work has been carried out on place identification/attachment (Lewicka, 2011), but the field of studies on urban identity as collective perception ("who are we as inhabitants, firms and institutions, of this city") and how others perceive the city, is far less evolved. Coming back to the point of homogenization/localization, the question can be asked for the Rotterdam case: can urban identity be lost, and is this what citizens experience or what outsiders observe? Or is identity not lost, but is it merely developing, becoming less specific or just different? Lewicka (2011) discusses the question 'is place important?'. She suggests that despite the growing number of the so called non-places, not only have places not lost their meaning but their importance in the contemporary world may have grown. She cites Casey (1997: p. xiii) “... the encroachment of an indifferent sameness-of-place-to the point when at times you cannot be sure which city you are in, given the overwhelming architectural and commercial uniformity of many cities, makes the human subject longs for a diversity of places, that is, difference-of-place on a global scale". The process of homogenization and localization is typically from a spatial and environmental view of urban identity. This human subject Casey speaks of, must be the people who travel the world and long for diversity. It is not the great mass of people; how they are attached to the city, may be quite another issue. It is time that they are asked about their attachment to the city, what it means for them to contribute to a healthy, clean, peaceful and productive place to live. That gives opportunities for future research and practice. Community-led research may clarify which stories are important to communities and feed into the discussions on urban identity. Given a lack of theory and appropriate quantitative methods, an examination of urban identity is bound to be qualitative, as will be the following examination of 
Rotterdam. In the final section of this article, the discussion about is urban identity researchable' is revisited. In their study on urban identity of three Dutch cities, Dormans et al. (2003: p. 22) consider urban identity as a process and point out that different actors construct visions of an urban identify. They relate identity to three domains; the physical, economic and social. In the following narrative of Rotterdam, this frame of three domains will be used.

\section{Rotterdam ${ }^{1}$}

Rotterdam has a strategic location since it has an open connection with the North Sea through the New Meuse River. Rotterdam is divided in two parts (see: map on Photo 2) which are connected by three bridges, a tunnel for cars and bikes, a railway and a metro tunnel, and small taxi boats. The city has about 620,000 residents and this number is slowly growing. Rotterdam is the main city of the Rotterdam region (Rijnmond), which has about 1.1 million people.

14 May 1940 was an important and a bad day for Rotterdam. During the start of World War II, German planes bombed the city centre and overnight Rotterdam became a "city without a heart". Removal of debris started very soon after the bombing. Under German control, already in 1942, the inner-city area was cleared (Photo 1).

Several major changes have taken place in Rotterdam during the past decades. The reconstruction of the city in the first place, the development of Rotterdam as a port city and the new composition of the population. These changes have taken place in an age of globalization.

Physical development. After WWII, Rotterdam underwent a substantial physical transformation, and an extensive redevelopment program was initiated. Rotterdam lost its historical center and during the post-war reconstruction period, the city center was turned into a modern district. Other large cities in the Netherlands have a historic core, Rotterdam has a modern core. A new city center was realized in a modernist way, i.e. separation of functions (residential, retail, offices) and emphasis on traffic infrastructure. After WWII, important developments in other parts of the city have taken place too, especially greenfield residential development for the growing labor force in the harbor. The development of new port areas Botlek (1955-1966), Europoort (1957-1970) made Rotterdam the world's largest port back in 1962. Maasvlaktel and 2 (1967-present, M1 and M2 in Photo 2) facilitated the further growth of the port activities.

With the shift from harbor activities to the shore, Rotterdam started to redevelop derelict harbor areas in the city, to integrate "water and city", as it is called. McCarthy (1998) concludes that local politics in Rotterdam in the 1970's and 1980 's were characterized by pragmatism, illustrated by the willingness of the municipality to engage in public-private partnership arrangements for development. During the first years after 1945, construction heights in the city center

${ }^{1}$ Below, major changes are briefly described, based on the recent accounts of Van der Horst (2017), Frijhoff (2015), Stadsarchief Rotterdam (2015) and Van Oudenaarden \& Vroegindeweij (2015). 


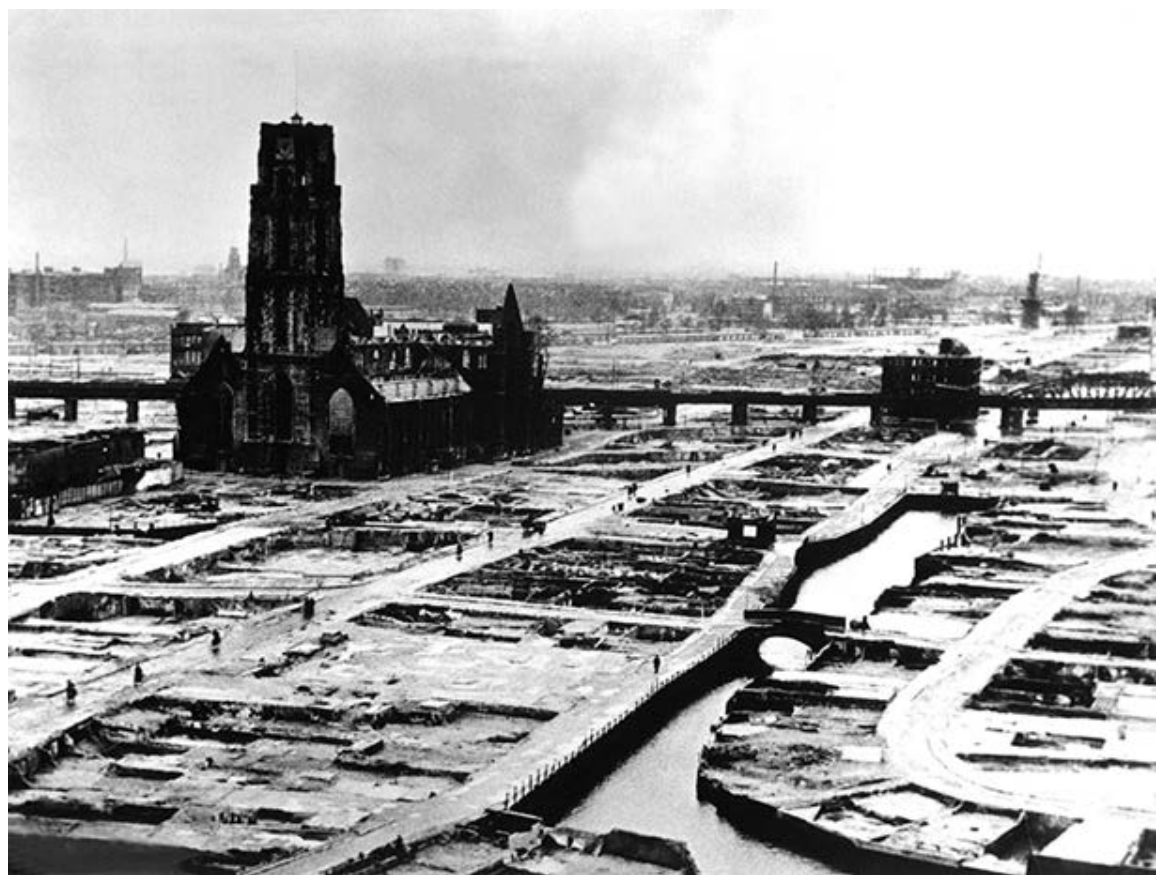

Photo 1. Rotterdam's city centre after the bombing. Source:

http://www.archives.gov/research_room/arc/ ARC Identifier: 535916; U.S. Defence Visual Information Center photo HD-SN-99-02993 (public domain).

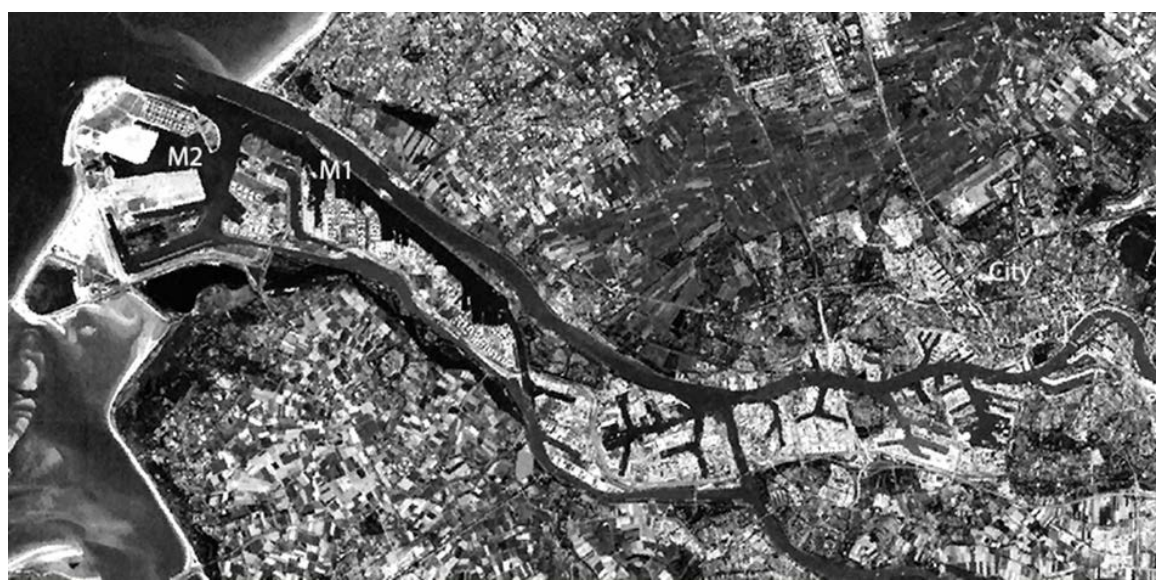

Photo 2. Map of Rotterdam City and Harbor. M1 is Maasvlakte 1, M2 = Maasvlakte 2. Source: Satellite image NASA, WikiCommons.

were limited to 8 - 10 levels. After 1960 more high rise and special architecture appeared. "Till 1970, Rotterdam was a relatively small and cozy city, but with a certain identity crisis due to historical discontinuation of its development progress." writes Čamprag (2014: p. 204). Cozy is not what the people of Rotterdam thought about their city center, they found it windy, cold and grey (Rotterdam Festivals, 2016b). From the 1970's onwards, the urban, economic and cultural climate of the city changed. A new urban plan opted for a more compact city, with mixed land-use and taller buildings. In 1970 the Medical Faculty was the first building over hundred meters (except for the Euromast observation 
tower), and many more buildings followed. Rotterdam came to be recognized as a progressive city in terms of architecture and waterfront development, with high-rise residential and office development and special architectural designs. The sky-line may attract much attention, but redevelopment and extension of the port, the massive residential development in the outskirts of Rotterdam and the neighboring municipalities and the upgrading of the housing stock, have been major developments too. The physical lay-out in Rotterdam still bears on the port function, as can be seen on the map below (Photo 3 ).

Rotterdam has a number of architectural attractions (local "icons"), that are described in all tourist guides, like the reconstructed Central Station and the Market Hall (see Photo 4 and Photo 5). The Erasmus bridge (see Photo 8) over the Meuse connecting the north and south parts of the city, has become the city's most significant landmark, for citizens and visitors alike. Rotterdam's architecture has contributed to the recent increase in tourism. Favorable reviews in international magazines, and prices such as the award for the 2015 European City of the Year given by the Academy of Urbanism, helped. Like other big Dutch cities, Rotterdam has a challenging urban development agenda.

\subsection{Economic Development}

Rotterdam shares an economic development pattern that can be witnessed in many European post-industrial port cities-old industries and the need for new employment. Rotterdam's port moved out of the city. Closer to the sea new harbour areas were developed that enabled larger ships to enter, and petrochemical and other industries to build modern large-scale plants.

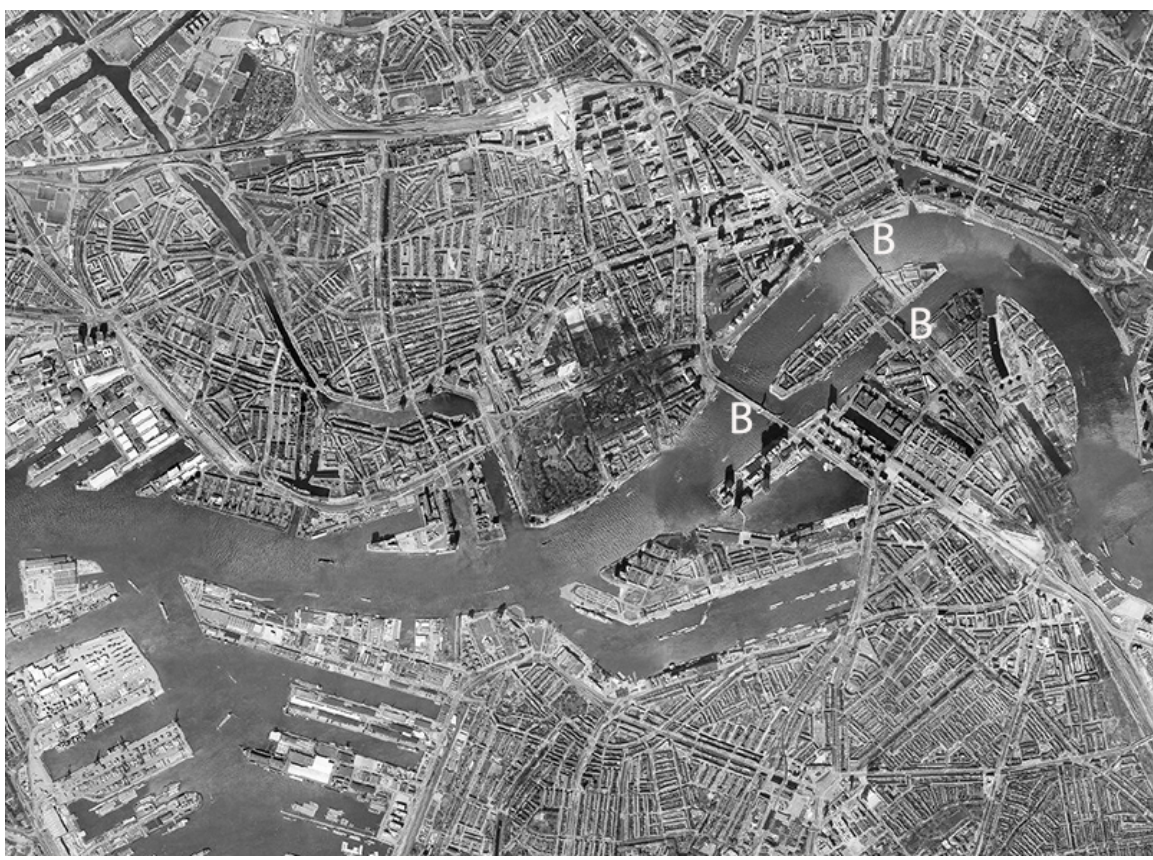

Photo 3. Map of Rotterdam city. B = bridge over the river. Source: maps.rotterdam.nl (public domain). 


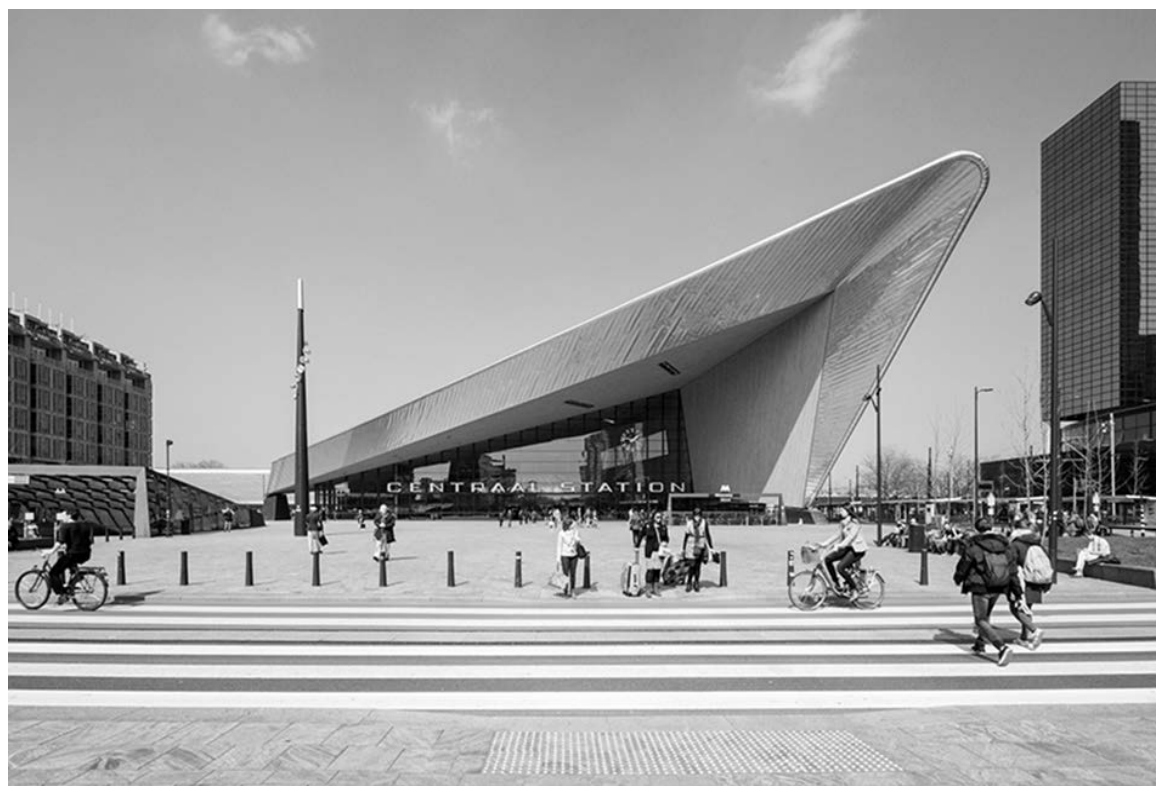

Photo 4. Reconstructed central station. Photo: O. van Duivebode, Source: Rotterdam Partners.

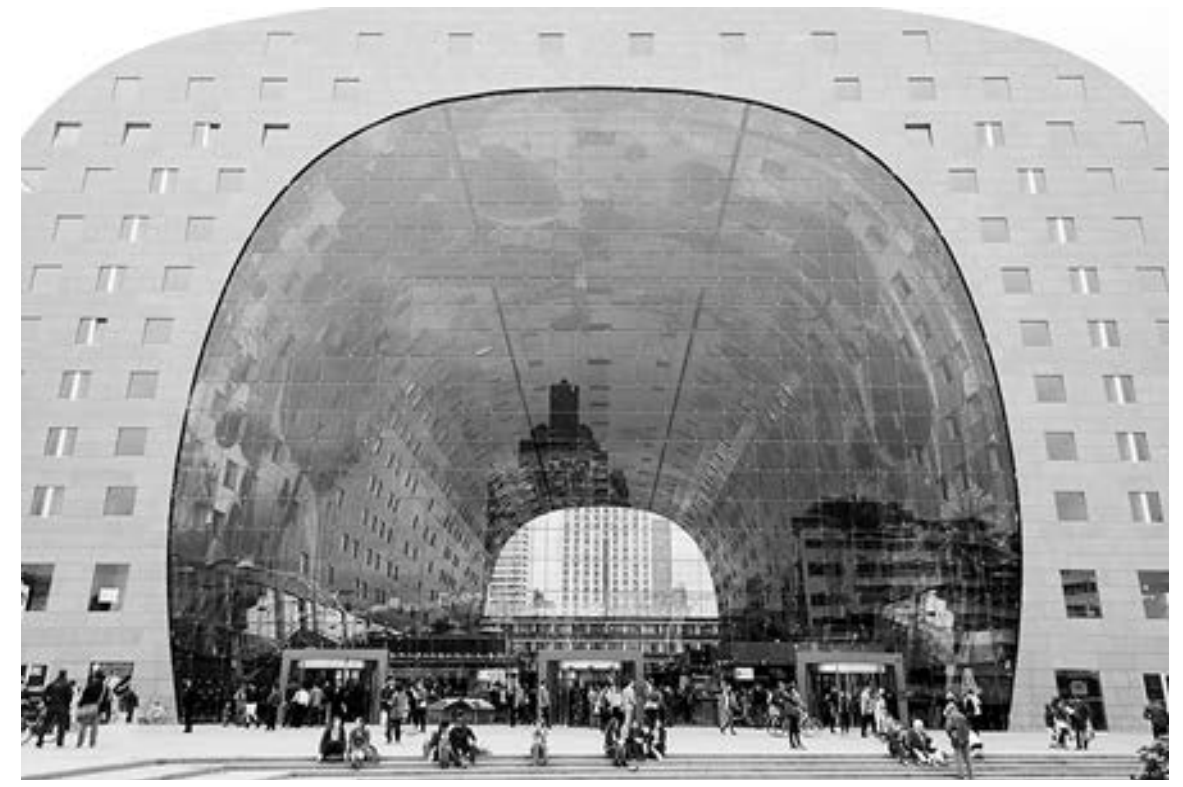

Photo 5. Market Hall (photo: Peter Nientied).

The development of container logistics impacted all infrastructure. Important has been the automation of the harbour. As a harbour city, Rotterdam benefitted from globalization. The Port of Rotterdam became the world largest port by annual cargo throughput in 1962 and kept that status till 2004, when Shanghai became number one. Rotterdam's port is still the biggest port in Europe and the 11th biggest in the world. The nature of harbour work changed, from mainly unskilled muscle before WWII, to highly skilled professional work nowadays. The number of people needed to handle all cargo decreased, due to the automation (see Photo 6). 


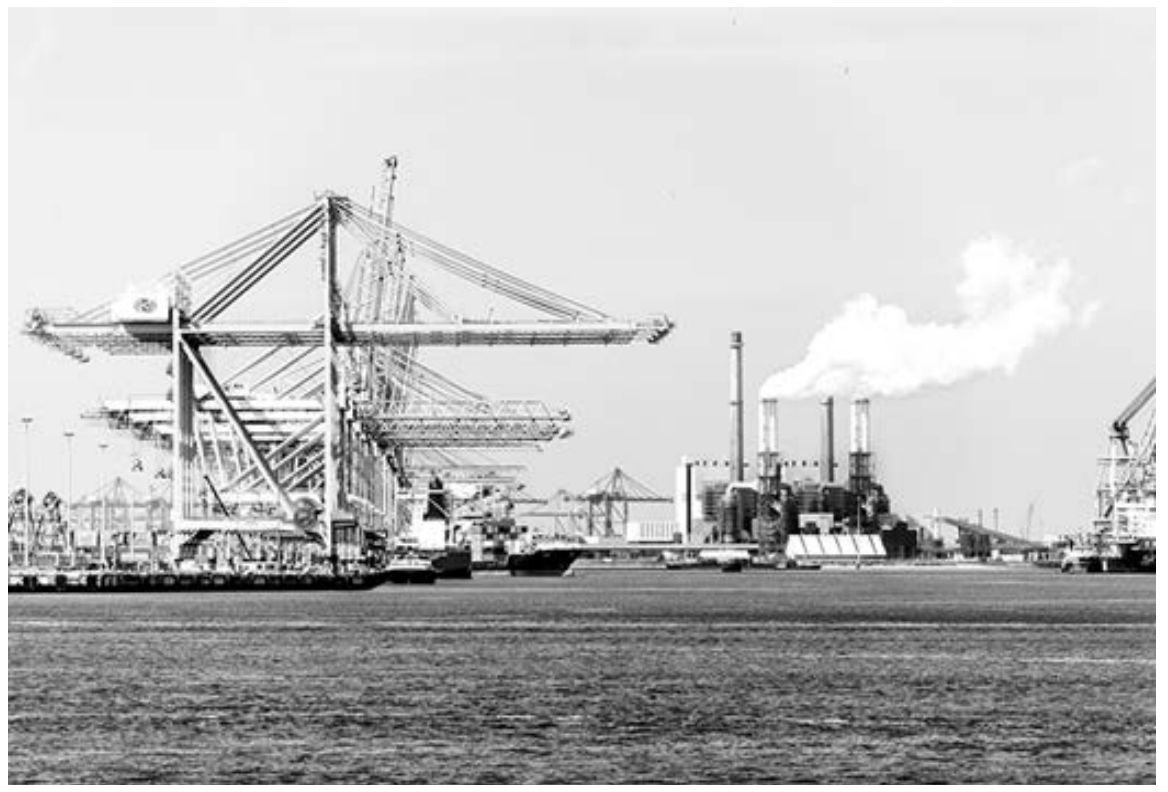

Photo 6. Rotterdam Harbour. Photo: O. van Duivebode. Source: Rotterdam Partners Editorial Royalty Free.

Engineers, IT professionals, planners, specialists in logistics, economists, etc. are the current professions in the harbour. In the city proper, located at some $30 \mathrm{~km}$ from the sea, only smaller boats can be seen, plus some bigger cruise ships. Like in other European post-industrial port cities, the urban economy has changed in Rotterdam. Unemployment is Rotterdam is still a bit higher compared to other Dutch cities-mainly because of the mismatch between labour market demands and education and skills levels (Stadsontwikkeling gemeente Rotterdam, 2017). The municipality tries to stimulate the creative economy, through giving support to education, subsidies and place making (Gemeente Rotterdam, 2016), with some success.

McCarthy (1998) points at the entrepreneurialism during the process of reconstruction, that included a strong focus on city marketing and "re-imagining" the city. The downturn in port-related activity (in terms of low skilled employment) demanded other types of economic development. Also, the city's potential for new high-profile schemes was recognized; prominent but underused areas such as waterfronts which could be developed for prestige office uses, high-quality housing and cultural or tourism facilities, all of which could improve the profile of the city within the Netherlands as well as internationally urban marketing.

\subsection{Demographical and Social Development}

While Rotterdam was always an international city due to its harbour, its resident population was mainly Dutch, with a substantial influx of workers from southern provinces in the Netherlands beginning in the late 19th century. Due to the need for labour in harbour related activities, immigration started from the 1960's onwards from countries like Spain, Cabo Verde, Portugal, and later Morocco 
and Turkey. Immigration due to family reunion signified a next wave and in the 1980 's, people from former colony Surinam and the Dutch Antilles came to Rotterdam. And since about 2000, international students and workers from Central and Eastern European countries followed (Entzinger \& Engbersen, 2013; Engbersen, 2014). In 2016, 49.8\% of the population was allochthonous [has-what is nowadays called in the Netherlands-a migrant background or have parents with a migrant background (Gemeente Rotterdam, 2017b)], 37.6\% of them "non-western" and 12.2\% "western". The percentage of autochthonous inhabitants, decreased to below 50\% in 2017, and will further decrease. Similar processes take place in The Hague and Amsterdam. Rotterdam has many nationalities, each with own cultural roots. First generation migrants settled and got children and these families feel different about the city-they have different attachments to the classical values and history of Rotterdam.

An important development has been the increased labour participation of women (Van den Berg, 2017). She analyses the 'masculine' character of Rotterdam's image (typically, white male, working class, port related, entrepreneurial, non-nonsense) and concludes that women and migrants had an equally important contribution to Rotterdam's economy.

In the decades after WWII, working class housing received priority in Rotterdam. Higher income groups settled in suburbs and surrounding municipalities. Rotterdam's ambition during the last two decades has been to attract more middle-income groups. This policy is slowly showing results; in redevelopment areas priority is given to middle class housing. This has resulted in gentrification and more spatial segregation between western allochthonous and autochthonous in middle and higher income other areas and mainly non-western allochthonous groups in the social housing sector (Gemeente Rotterdam, 2017b; Van Boven, 2017). In these areas, also social vulnerability is prominent (lower educational levels, unhealthy lifestyles, higher unemployment).

\section{Rotterdam's Identity 15 Years Ago}

In their study "The city narrates of the city", on culture and identity in Rotterdam, researchers Fortuin and Van der Graaf (2006) offered a picture of "typical Rotterdam". Based on empirical work carried out in 2002-2003, they gave a series of key words describing the identity of Rotterdam. Rotterdam, they suggested, is an-aspiring city, people look towards the future, the city is action orientated; it is a-city of the people, with direct communication and with a preference for low culture (mass events for example); and it is an-open city, with space for realizing plans, a city for future seekers, young people and migrants. Fortuin \& Van der Graaf (2006) further portrayed Rotterdam's identity under the following headings.

- Rotterdam as a port city, with a rolled-up sleeves mentality. The port has physically moved to the shore areas, and port employment has gone down. Rotterdam as "water city" with a waterfront development high rise sky line is 
obvious. The culture of hard work, direct communication is typical.

- City without a heart, space for the new. Rotterdam constructed a new city center, that was open rather than "warm". It is in line with a preference for the future rather than the past.

- The second city. Rotterdam competes with Amsterdam. Its position as second city has led to a competitive attitude, desiring to be better than Amsterdam.

- "Low" culture, mass events and popular culture fit Rotterdam's "rolled up sleeves" mentality and are preferred over "elitist" culture. Perhaps, say Fortuin and Van der Graaf (2006: p. 24) this can be understood in relation to inferiority feelings towards Amsterdam with its high culture.

- Aspiring city-a reconstructed, open city with many newcomers is a city that looks forward, tries to achieve positions. Looking forward is more important than looking backward.

- Internal diversity, Rotterdam is a city with villages. The northern part has luxury neighborhoods (and working-class neighborhoods) whereas the southern part is the more backward part.

- A city for young people. Rotterdam has comparatively more young people, and a corresponding culture. Young people appreciate Rotterdam as a modern city.

- A minority city. Because of the port, Rotterdam always was an immigration city attracted ethnic groups, and has developed into a city with many nationalities. Their presence leads to cultural dynamics, which in turn will have a yet unknown change in the individuality of the city.

15 years after their empirical research, a fresh look is taken on these eight ascribed identity features of Rotterdam.

\section{Rotterdam's Identity Now}

\subsection{Rotterdam as a Port City, with a Rolled-Up Sleeves Mentality}

Rotterdam used to be proud of its rolled-up sleeves mentality. This mentality was understood as a culture of hard work, of complaining about the city and loving the city at the same time, direct communication and a no-nonsense attitude (cf. Hoogstad, 2018). Börger et al. (2016) point out that the city is now quite different from the city some 15 years ago. At that time, negative news about Rotterdam was prominent, Rotterdam appeared in the press as an unsafe city, a city with high employment, an unattractive city. Liukku \& Mandias (2016) discuss about the new élan and Rotterdam's "comeback", and Hoogstad (2018: p. 11) speaks about the metamorphosis of the city. An increasing number of tourists visit the city to enjoy the skyline and waterfront development (Photo 7). The economy improves and unemployment decreases, international media have discovered Rotterdam. Van den Berg (2017: p. 37) makes a comparison between European post-industrial port cities of Marseille, Antwerp and Rotterdam, and concludes that they "... use a cultural repertoire to balance out negative images 


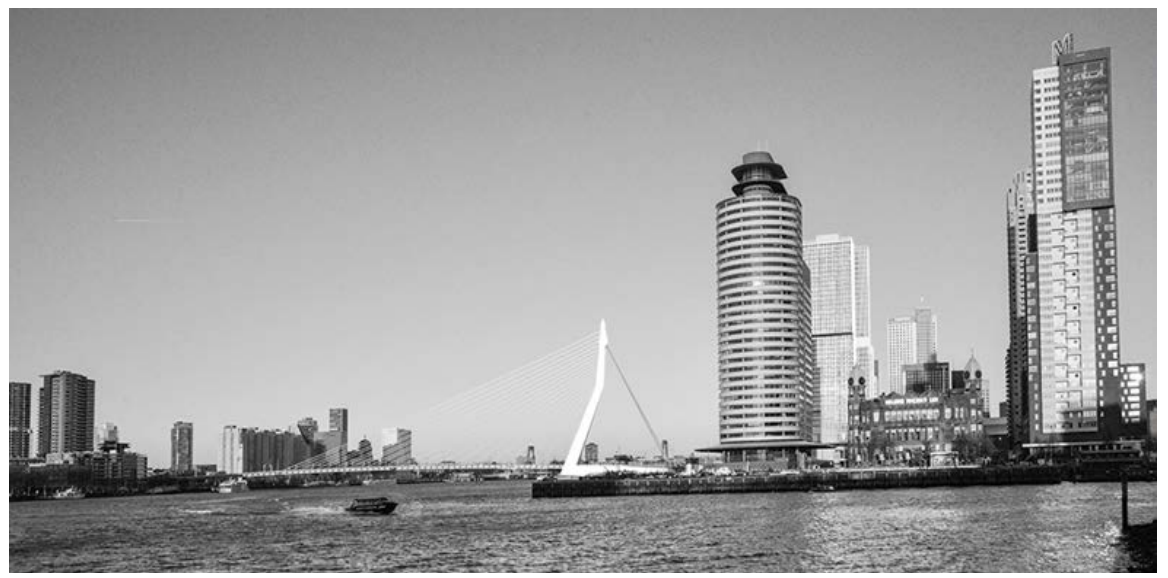

Photo 7. Skyline Rotterdam with Erasmus Bridge (photo: Peter Nientied).

about their city and especially imagery of roughness. These are examples of cities that deal with hardships that are the result of economic restructuring, the transition to post-Fordism and interurban competition." She explains three concrete myths; ".. that seem 'natural' within the mythology of the harbor and World War II: the 'international allure', the 'no-nonsense attitude' and the 'working class/blue collar' identity, which appears as a 'muscleman' and extremely masculine." (ibid., 42, quotation marks in the original).

The youngest population groups have the most positive opinion about the city (Gemeente Rotterdam, 2017a). This could be related to collective memory: younger people just have less collective memory and they think of the reconstruction of the city as something historical. As far as the rolled-up sleeves mentality is concerned, most Rotterdammers would agree that a no nonsense and direct attitude would characterize the inhabitants. The old feeling of Rotterdam as port city gradually diminishes-the port is far away. Due to the river and other canals, the renovated old port areas within the city, and the urban planning efforts to create waterfront developments, the link with the river Meuse is strong, but it signifies a link with the river rather than with the port. There is some nostalgia in the discussions of what is typical Rotterdam. As De Jong (2016) in his presentation about the future of the harbor in relation to the city explains, the notion of Rotterdam as a harbor city has been romanticized. In a study of SS Rotterdam, a classic cruise ship that has been turned into a hotel and is one of Rotterdam's visitor attractions, the same was found (cf. Nientied, 2016).

\subsection{The Second City}

Urban identity is always in relation to a wider context. Amsterdam as first city of Holland was said to be important for Rotterdam as second city, but the "second city syndrome" that Maarse (2016) still speaks of (and Fortuin and Van der Graaf (2006) too) is not a significant factor in the city. There are still some competitive "underdog" feelings in Rotterdam towards Amsterdam, but they are rather insignificant. Börger et al. (2016: p. 40) report op basis of empirical work 
that the second city syndrome is not alive, the comparison is just not made in minds of people. Due to the development of Amsterdam's financial center, its airport and tourism, and with a thriving creative and start-up sector, Amsterdam's economy is far bigger than Rotterdam's economy (CBS, 2017). The economic development of Rotterdam during the last decades, has been lagging the development of other large cities of the Netherlands (Gemeente Rotterdam, 2017a, 2017b). In short, Rotterdam is not hunting for a first position, but it struggles to keep at pace with other big cities (Hoogstad, 2018). A different item to illustrate the wrongly assumed second city syndrome concerns Rotterdam's mayor Aboutaleb, who was proposed in 2008 as the best candidate to be mayor of Rotterdam. Two points are noteworthy here: he is born in Morocco and has an Islamic background (and the first Morocco born mayor in Western Europe) and second, he is from Amsterdam where he served as an alderman. His Amsterdam past was not an issue for the municipal selection committee.

\subsection{Low Culture}

Rotterdam has comparatively less theatres and other cultural spaces than other big cities in the Netherlands. Mass events and popular culture are preferred over elitist culture, claimed Fortuin and Van der Graaf (2006). In his presentation, Van Eijck (2016) took up the question of local magazine and platform Vers Beton "Is Rotterdam a typically low-culture city?". In a comparison with Amsterdam and The Hague (typically "high" culture cities), van Eijck shows with statistics that differences are not as big and that they can rather easily be explained by two social indicators: compared to other big cities in Holland, Rotterdam has a younger population and it has a higher percentage of lower educated citizens. These groups indeed tend to prefer the summer festivals over opera and ballet. But, citizens of Rotterdam do not prefer low culture, if controlled by variables age and education.

\subsection{Internal Diversity, Rotterdam Has a Number of "Villages"}

Internal diversity is inherent to a large city-history, social stratification etc. can be found in all bigger cities in Holland, perhaps the whole world. Diversity in Rotterdam increases-like in other cities (Landry, 2017)-due to globalization processes. Within the "village", diversity increases and culture changes. Old social relationships become less important, new social relationships develop.

Fortuin \& Van de Graaf (2006) point at different neighborhoods, but they do not pay attention to the fact that Rotterdam is also a segregated city (Engbersen, 2014). Hoogstad (2018), in his recent review of the modern political history of Rotterdam, refers to Rotterdam as "city of two speeds". Segregation is not typical for Rotterdam, it is a pattern that can be found in all major cities in the Netherlands. For the last two decades, local government has favored middle and higher income housing development and has made progress in this direction. In areas ("villages") like Katendrecht and Overschie, old social housing is demolished 
and replaced by middle income housing. Gradually, the social structure of old neighborhoods is mixed with new middle-class residences and new retail.

\subsection{A City for Young People}

Rotterdam has, compared to other big cities in the Netherlands, a somewhat younger population. The economy changes (Gemeente Rotterdam, 2017b) and shows that younger people with good education can easily find jobs, and that several younger people nowadays choose Rotterdam as their preferred city to start a business. In terms of distinctiveness-and that is what identity is about-the question is whether Rotterdam attracts more young people that other places. Figures are not available, but the impression is that other cities perform better in this regard, especially Utrecht, Eindhoven and Amsterdam. The explanation is easy: their economies outperform the economy of Rotterdam and they have, comparatively, more higher education institutions.

\subsection{A Minority City}

In Rotterdam, all social and ethnic groups are minorities, since 2017 the autochthonous Dutch community is smaller than $50 \%$ of the total population. In general, the Dutch have become somewhat more tolerant towards people with a migrant background. Social and Cultural Plan Office (SCP, 2017) summarizes their national level research as follows, though percentages answering "yes" to the following question (Table 1) (cf. Engbersen, 2010).

Table 1. Opinions about people with different nationalities. Source: SCP (2017: p. 75, translation of the question by PN, figures from the database Stateline of Central Statistical Office CBS, 15-12-2017).

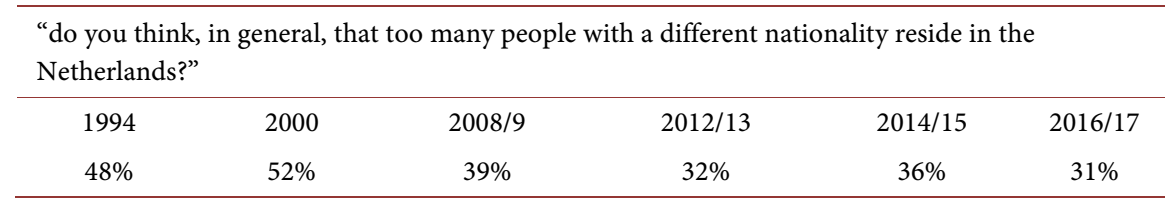

It is likely that this trend can also be witnessed in Rotterdam. Tensions between groups sometimes emerge in Rotterdam, in 2017 for example between different factions of the Turkish community after one of Erdogan's ministers was refused to hold an election speech in the city. Discrimination and segregation are issues in all major cities in the Netherlands. There are correlations between belonging to an ethnic non-western minority, low education and lower incomes. The housing market influences which neighborhoods are inhibited by low-income groups, often people with low education, longer term unemployed and with a migrant background. That means segregation. Bovens et al. (2014) argue that education rather than ethnic group, is a proxy of social-cultural differences, but there is a lack of understanding regarding the exact relationship between education and social-cultural differences.

Local government does not talk about minorities, the topic looks to be care- 
fully avoided. The narrative is "everybody is citizen of Rotterdam". This looks positive, but is it? Not discussing social-cultural differences may mean that people who have concerns, do not feel that they are heart. Right wing political parties in Rotterdam have gained many seats in the local council since 2000.

The minority city, the super diverse city, has challenges. Börger et al. (2016), based on a 2015 study of 101 respondents on how citizens experience the inner city, report that young people are positive about the multicultural city, and older people tend to become cynical about it. "It looks like as if we are proud of the diversity in the city, but that we find it difficult to deal with in in daily life... The big mission for the city is how we can really live together in a superdiverse city community." (ibid., 2016: p. 43, translation by PN). In the background report of "Verhaal van de Stad" (story of the city) (Veldacademie, 2017) the following Table 2 has been given, based on answers of over 2500 respondents.

Table 2. Opinions about cultural backgrounds. Source: Stadsontwikkeling gemeente Rotterdam, 2017: p. 19.

\begin{tabular}{lc}
\hline In 2037 Rotterdam will have even more different cultural backgrounds How do you & $\%$ \\
look at this? & 6.9 \\
\hline I increasingly feel less at home in Rotterdam & 11.4 \\
I want less differences & 21.9 \\
I am neutral & 34.0 \\
A bit of diversity is better & 25.8 \\
Diversity is positive! It is part of Rotterdam & \\
\hline
\end{tabular}

Some answering categories are not very clear, but this is not explained. Moreover, it can be imagined that there is an (unknown) factor of socially acceptable answering in this large-scale survey (Veldacademie, 2017). Survey outcomes per ethnic group and according to level of education and age have unfortunately not been recorded.

\section{Reflection}

In the previous section, some of the notions of what is "typical Rotterdam" as identified by Fortuin and Van der Graaf (2006) have been looked at from a present-day perspective. The context has changed; Rotterdam is now recognized as an attractive city for visitors, the economy is slowly improving (but other cities in the Netherlands are doing better), the diversity of the population has further increased, like in Amsterdam and The Hague. The physical development of the city continues to play an important role. The satisfaction of residents with their neighborhoods has increased (Gemeente Rotterdam, 2017b). Looking back, it is remarkable that Fortuin and Van der Graaf (2006) were not critical of what is typical Rotterdam. Perhaps this is inherent to the notion of identity, that in a search for what is distinctive, positive elements tend to dominate. After all, urban identity is in the realm of collective attribution, it is a quality in the collective minds of citizens in a city. Individual and collective self-perceptions tend to have a positive bias-albeit that notions of collective self-esteem, social identity 
theory and a self-serving bias, are debated and, as far as we could find out, not researched in current Western European conditions. Fortuin and van der Graaf (2006) were rather unconcerned with attributing quasi-psychological characteristics to the citizens and the collective urban identity of Rotterdam. It was their reading, their view, of what is typical for Rotterdam. Minority issues were avoided, and the point that Rotterdam was lagging and getting further behind in terms of economic indicators, was also left undiscussed. Their viewpoint was not contested. Looking back now, their report was a rather comfortable interpretation of Rotterdam's urban identity.

Van den Berg $(2017,2018)$ adds an important dimension to the image of what was and to an extent still is typical Rotterdam. The image ("myth" is the term Van den Berg uses) is masculine. "There was a time when presenting Rotterdam as tough and masculine was no problem at all. Especially during the years of industrial expansion, Rotterdam and Rotterdammers prided themselves on their toughness. Although this repertoire is still very much in place today and selectively used, it seems that to be a 'tough' and 'masculine' city with only 'balls' and no 'tits' is not enough in the post-Fordist era." (ibid, 2017: p. 32, quotation marks in original). It is expected that this message is quite difficult to grasp for a "masculine" city like Rotterdam.

\section{Local Government and Identity Formation}

During the last three years, Rotterdam's local government has initiated three programs that relate to the question of identity. They will be briefly reviewed.

\subsection{The DNA: Make It Happen}

In 2014, Rotterdam's local government developed a new narrative of the "DNA" of Rotterdam. The aim was to give a clear profile of the city, assuming that this enhances the willingness of people and organizations to cooperate for a better city. ${ }^{2}$ The DNA has three headings: 1 . International; 2. Entrepreneurial, and 3. Edgy (raw). A pay-off for the city was developed: "Rotterdam. Make it Happen". ${ }^{3}$ This replaced the old slogan "Rotterdam World Port World City". The new pay-off is consistently used by the Port Authority, Erasmus University and the Municipality-organized for this purpose in "Rotterdam Partners" (see Photo 8 below). Since launching the program, other organizations have joined this partnership. For city branding purposes, the pay-off Make It Happen sounds good for visitors and business, and for residents too. Important is that the word "world port" has been deleted. For branding purposes, Rotterdam wants to show that it is more than a port city and wants to highlight its entrepreneurial character.

\subsection{Years Reconstruction of the City}

In 2016 the Municipality celebrated "75 years of reconstruction of the city"4, a ${ }^{2}$ http://www.rotterdam.nl/bestuur-organisatie/dna

${ }^{3}$ http://www.rotterdammakeithappen.nl

${ }^{4}$ http://www.rotterdamviertdestad.nl 


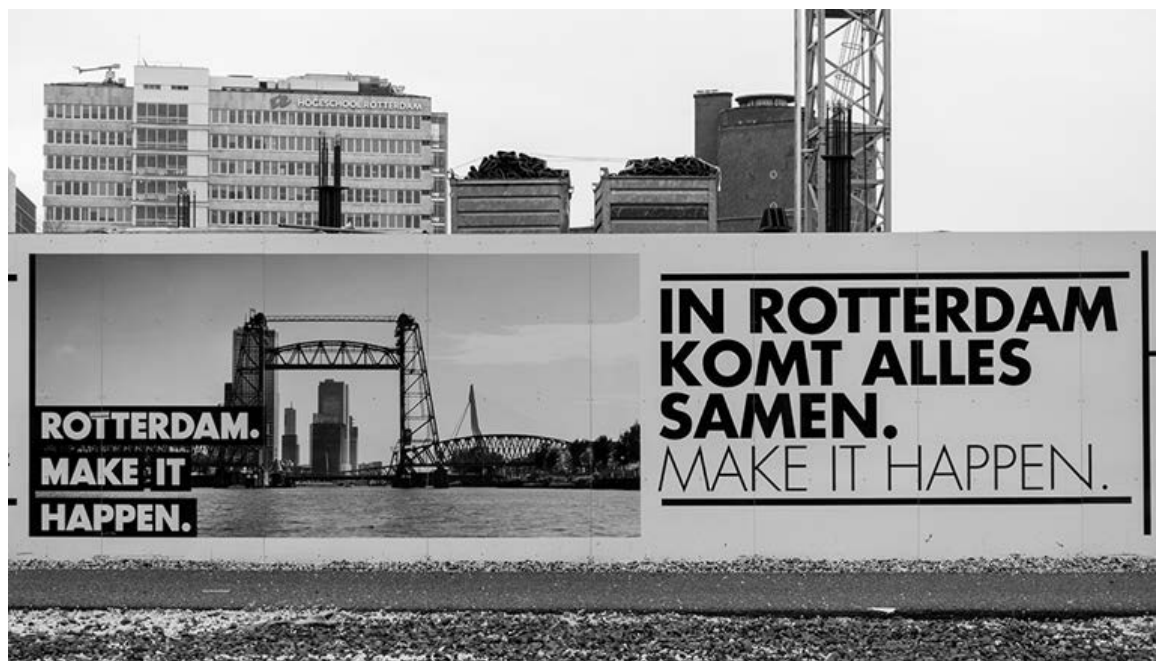

Photo 8. "In Rotterdam everything comes together-make it happen." In front of the extension of the Boijmans museum. (Photo: Peter Nientied).

cultural manifestation with more than 100 projects and 75 stories shared by citizens from all corners and all walks of life (Rotterdam Festivals, 2016a: p. 105, 2016b). The program was meant to be a celebratory and collective dialogue about the city and its future. The issue of post war reconstruction and collective memory was discussed, and it was recognized that many newcomers to the city, are not part of this collective memory. The city is and should be a meeting space, is one of the conclusions. This is what the respondents indicate, and it is somewhat elusive, conclude Kraaij et al. (2016).

\subsection{The Story of the City}

The third program was also a substantial endeavor. In 2017 the municipality implemented the program, The story of the city", with "Rotterdam in 2037" as a lead theme. It has been a mass participation project, in which more than 9000 people were involved. In the G1000 (citizens top meeting G1000), more than 1000 people met on a Saturday to discuss topics like education, living together in the neighborhood and radicalization, and harmony in the city. Veldacademie (2017) did a lot of field work and interviewed many people, from different walks of life. Their report shows that Rotterdam's citizens want a positive future, with work, a nice environment, good education, a say in decision making, and so on. In terms of contents and policy issues, there were no surprises at all: people want good things for the city, for their neighborhood and for themselves. The significance of the program "The story of the city" has been the mass participation, not the city aspirations of people. In terms of urban identity, not much can be deducted from this program.

The three local government programs can be regarded as local government actions to influence urban identity formation; they aim at the creation of an ad-

${ }^{5}$ http://www.hetverhaalvandestad.nl 
justed story of what Rotterdam is and what its future should be. There are of course numerous other programs in the Rotterdam that influence identity building, on the built environment, education (KCR, 2017), culture, mainstreaming of the diversity issues, etc. The three programs had an integrative character and were focused on a positive story of Rotterdam. Rotterdam's city branding is built on the local government's view of the DNA of Rotterdam, and through the programs 75 years Reconstruction of the city and the story of the city, this view of Rotterdam's DNA has been shared with the public. Whether the public remembers much of these stories, can be questioned. The three programs with different manifestations, portray the city in a rather harmonious and future orientated manner. Indeed, the stories of citizens, entrepreneur and visitors, are positive-there is no reporting of what social dropouts think about special care, what right wing citizens think about migrants and mosques, which patterns can be found in the city's criminality figures, etc.

\section{Conclusion}

Fortuin \& de Graaf (2006) stress that identity should be discussed as a process, not as a fixed entity. In this article it was argued that several aspects that Fortuin \& de Graaf (2006) described, have changed and other aspects of their picture of what is typical for Rotterdam, got another interpretation. The campaigns of the municipality affecting identity, have been successful in terms of participating crowds. The campaigns search for harmonious relationships and economic development for the city. The pay-off "Make it happen" is a call to visitors and companies to come to Rotterdam and the promise is that companies can make it happen and that the local government is there to help. Referring to different minorities, Engbersen (2014: p. 12) suggested that the local government should tell a motivating integration story. Through the program The story of the city, the municipality has tried, but this attempt is far from convincing. The frame of the campaign-how discussions were organized-was in categories like education, environment, future work and culture, the policy categories one finds in municipal policies. And, no surprise was that Rotterdam's citizens want a positive future. The results of the participation do not in any way conflict with ongoing local government policies. The results will have limited impact on local government since difficult social-cultural issues were avoided. This exercise has not been the stimulating story (on diversity) that Engbersen (2014) asked for. That would demand a clear picture of the current situation and an appealing sketch of the future of the city and what is asked from the citizens.

From an economic angle, Maarse (2016) explains that the city requires a structural transformation of its economy. The importance of the chemical industry and the port, is bound to decline in the longer run. A solid cultural infrastructure is needed, quite different from the ad-hoc big cultural festivals (cf. EESC, 2016). Such realism and vision are not well developed in the current optimism of the city. "Rotterdam's economy is going well", is the start of the Eco- 
nomic Study 2017 (Stadsontwikkeling gemeente Rotterdam, 2017), but compared to other large cities in the Netherlands, Rotterdam is lagging. Rotterdam's urban identity bears the history of the reconstructed city and the transformed port. The port and reconstruction identity becomes a minority identity. Mirant groups cherish their native culture. For the newcomers and younger generations, the reconstruction identity is mostly history. The reconstruction identity also fails to satisfy a current need for a modern image of the city: an entrepreneurial city that makes things happens, is not built on masculine rhetoric, but needs to develop gender and femininities as strategic instruments (Van den Berg, 2017). Rotterdam's identity becomes more hybrid. In processes of globalization, people may need local roots, but whether these roots are based on place, or on social and ethnic bonds, remains a question.

A final point is submitted on the limitations of this research. This study signifies qualitative work, given the lack of theory and appropriate quantitative methods, as explained in the review of urban identity theory. The qualitative approach implies interpretation of the many voices, materials and studies on Rotterdam, and most likely a certain bias of the researcher who reflects on a city he knows quite well. This is unavoidable in searching for meaning and significance of a city for their inhabitants and users. Ideally speaking, other studies on Rotterdam's urban identity should complement the present study. In general, case studies on urban identity that go beyond impressionistic accounts are needed to develop the field of urban identity. The concept of place attachment is well explored, but urban identity as Cheshmehzangi (2015) speaks of, as a cultural identity as a basis of distinctiveness determining qualities that exist only in a particular place, is not.

\section{References}

Adams, R. (2011). The Globalisation of Place (pp. 36-45).

Bell, D. A., \& de-Shalit, A. (2011). The Spirit of Cities, Why the Identity of a City Matters in a Global Age. Pinceton: Princeton University Press.

Berger, T. (2016). Place, Imaginary, Identity: Place Ethnography in Truth or Consequences, New Mexico. PhD Thesis, Albuquerque: The University of New Mexico. http://digitalrepository.unm.edu/amst_etds/45

Börger, J., Van de Laar, P., \& Liukku, E. (2016). Rotterdam, the Neverending Story (pp. 34-46).

Bovens, M., Dekker, P., \& Tiemeijer, W. (2014). Gescheiden werelden? Een verkenning van sociaal-culturele tegenstellingen in Nederland. Den Haag: SCP/WRR.

Čamprag, N. (2014) Urban Identity in Change, a Comparison between Frankfurt and Rotterdam. PhD Dissertation, Darmstad: TU.

Casey, E. S. (1997). The Fate of Place. A Philosophical History. Berkeley, CA: University of California Press.

CBS (Centraal Bureau Statistiek) (2017). De economieën van Amsterdam en Rotterdam vergeleken. The Hague: $\mathrm{CBS}$.

Cheshmehzangi, A. (2015). Urban Identity as a Global Phenomenon: Hybridity and Con- 
textualization of Urban Identities in the Social Environment. Journal of Human Behaviour in the Social Environment, 5, 391-406.

De Jong, O. (2016). Is Rotterdam straks nog wel een havenstad? http://vimeo.com/166978628

Devine-Wright, P., \& Clayton, S. (2010). Introduction to the Special Issue: Place, Identity and Environmental Behaviour. Journal of Environmental Psychology, 30, 267-270. https://doi.org/10.1016/S0272-4944(10)00078-2

Dormans, S., Van Houtum, H., \& Lagendijk, A. (2003). De verbeelding van de stad: De constructie van de stedelijke identiteit van Arnhem, Groningen, Maastricht en Tilburg. Utrecht: University of Utrecht, NETHUR.

EESC (European Economic and Social Committee) (2016). Cultures, Cities and Identity in Europe. Brussels: European Union.

Engbersen, G. (2010). De gespleten identiteit van Rotterdam (Rotterdam Lezing 2010). http://www.youtube.com/watch?v=o8gKSrXegK0\&list=PLFDbd49eN_5NFdAU1TkNi 0Cva7IAq1zGi

Engbersen, G. (2014). Van zijstroom tot hoofdstroom van beleid, Integratie als permanente opgave voor de stad Rotterdam. Rotterdam: Erasmus University/Municipality of Rotterdam.

Entzinger, H., \& Engbersen, G. (2014). Rotterdam, A Long-Time Port of Call and Home to Immogrants. Washington DC: Migration Policy Institute.

https://www.migrationpolicy.org/research/rotterdam-long-time-port-call-and-home-i mmigrants

Evans, B., McDonald, F., \& Rudlin, D. (2011). Urban Identity. Abingdon: Routledge.

Filep, C. V., Thompson-Fawcett, M., \& Murray, R. (2014). Built Narratives. Journal of Urban Design, 19, 298-316. https://doi.org/10.1080/13574809.2014.890043

Fortuin, K., \& Van der Graaf, P. (2006). De stad verhaalt van de stad, Rotterdamse lokale identiteit en cultuur als hulpbron. Utrecht: Verweij-Jonker Instituut.

Frijhoff, W. (2015). Physical Space, Urban Space, Civic Space: Rotterdam's Inhabitants and Their Appropriation of the City's Past. In M. Beyen, \& B. Deseure (Eds.), Local Memories in a Nationalizing and Globalizing World (pp. 27-50). Basingstoke: Palgrave Macmillan. https://doi.org/10.1057/9781137469380_2

Gemeente Rotterdam (2016). Rotterdam Resilience Strategy-Ready for the 21st Century, Consultation Document.

http://www.resilientrotterdam.nl/wp-content/uploads/2016/05/strategy-resilient-rotter dam.pdf

Gemeente Rotterdam (2017a). Het verhaal van de stad (the Story of the City). http://www.verhaalvandestad.nl

Gemeente Rotterdam (2017b). Het verhaal van de stad, Rotterdam in Facts and Figures. http://www.verhaalvandestad.nl

Hauge, Å. L. (2007). Identity and Place: A Critical Comparison of Three Identity Theories. Architectural Science Review, 50, 44-51. https://doi.org/10.3763/asre.2007.5007

Hay, R. (1998). Sense of Place in Developmental Context. Journal of Environmental Psychology, 18, 5-29. https://doi.org/10.1006/jevp.1997.0060

Hoogstad, M. (2018). Rotterdam, stad van twee snelheden. Rotterdam: Trichis.

Karpovets, M. (2014). The Theoretical Background of Understanding Urban Identity in the Anthropological Perspective. Kyiv-Mohyla Humanities Journal, 1, 77-93. 
https://doi.org/10.18523/kmhj25712.2014-1.77-93

KCR (Kenniscentrum Cultuureducatie Rotterdam) (2017). Wanneer het kwik stijgt en de hoofden meer ruimte krijgen. Rotterdam: KCR.

Kraaij, R., Liukku, E., \& Specht, M. (2016). Toekomst in de maak terugblik op de publieke gesprekken tijdens de manifestatie Rotterdam viert de stad (pp. 56-68).

Lalli, M. (1992). Urban-Related Identity: Theory, Measurement and Empirical Findings. Journal of Environmental Psychology, 12, 285-303. https://doi.org/10.1016/S0272-4944(05)80078-7

Landry, C. (2017). The Civic City in a Nomadic World. Rotterdam: Nai010 Publishers.

Landry, C., \& Murray, C. (2017). Psychology \& the City: The Hidden Dimension. Gloucestershire: Comedia.

Lewicka, M. (2008). Place Attachment, Place Identity and Place Memory: Restoring the Forgotten City Past. Journal of Environmental Psychology, 28, 209-231. https://doi.org/10.1016/j.jenvp.2008.02.001

Lewicka, M. (2011). Place Attachment: How Far Have We Come in the Last 40 Years? Journal of Environmental Psychology, 31, 207-230.

Liukku, E., \& Mandias, S. (2016). Help, we zijn populair, Rotterdam stad in verandering. Rotterdam: Nai010 Publishers.

Maarse, G. (2016). Rotterdam: First Class Second City. Een zoektocht naar de Rotterdamse identiteit. Erasmus Magazine. http://www.erasmusmagazine.nl/2016/04/29/rotterdam-first-class-second-city/

Mah, A. (2014). Port Cities and Global Legacies: Urban Identity, Waterfront Work, and Radicalism. Basingstoke: Palgrave MacMillan. https://doi.org/10.1057/9781137283146

McCarthy, J. (1998). Reconstruction, Regeneration and Re-Imaging: The Case of Rotterdam. Cities, 15, 337-344. https://doi.org/10.1016/S0264-2751(98)00029-8

Nientied, P. (2016). Metaphors and Urban Studies-A Crossover, Theory and a Case Study of SS Rotterdam. City, Territory and Architecture, 3, 21. https://doi.org/10.1186/s40410-016-0051-z

Rollero, C., \& De Piccoli, N. (2010). Place Attachment, Identification and Environment Perception: An Empirical Study. Journal of Environmental Psychology, 30, 198-205. https://doi.org/10.1016/j.jenvp.2009.12.003

Rotterdam Festivals (2016a). Rotterdam viert de stad! In woord. http://www.rotterdamviertdestad.nl https://issuu.com/rotterdamviertdestad/docs/rf_rvds_digi_compleetl_101116

Rotterdam Festivals (2016b). Rotterdam, the Neverending Story, het publiek gesprek van de manifestatie Rotterdam viert de stad! Rotterdam.

Sandholz, S. (2017). Urban Centres in Asia and Latin America, Heritage and Identities in Changing Urban Landscapes. Berlin: Springer International Publishing Switzerland.

Scannel, L., \& Gifford, R. (2010). Defining Place Attachment: A Tripartite Organizing Framework. Journal of Environmental Psychology, 30, 1-10.

https://doi.org/10.1016/j.jenvp.2009.09.006

SCP (Sociaal en Cultureel Planbureau) (2017). De sociale staat van Nederland. The Hague: SCP.

Singer, T. (2010). Psyche \& the City, a Soul's Guide to the Modern Metropolis. New Orleans, LA: Spring Journal.

Solesbury, W. (2013). World Cities, City Worlds: Explorations with Metaphors, Icons and Perspectives. Leicestershire: Matador. 
Stadsarchief Rotterdam (2015). Het Rotterdam Boek (4th ed.). Zwolle: WBOOKS.

Stadsontwikkeling gemeente Rotterdam (2017). EVR 2017, Next Economy, Next City. Rotterdam.

Van Boven, J., Raatgever, A., \& Hoogerbrugge, M. (2017). Ruimte voor een stad in balans, essays over Rotterdam. Municipality of Rotterdam \& Platform 31.

Van den Berg, M. (2017). Gender in the Post-Fordist Urban, the Gender Revolution in Planning and Public Policy. Cham: Palgrave Macmillan.

Van den Berg, M. (2018). Kerel Is Dood. Laat zijn verhaal ons Rotterdams verhaal doen hervertellen. Vers Beton.

https://versbeton.nl/2018/01/kerel-is-dood-laat-zijn-verhaal-ons-rotterdams-verhaal-d oen-hervertellen/

Van der Horst, H. (2017). Rotterdam, Bruid van de Maas. Amsterdam: Prometeus.

Van Eick, K. (2016). Houdt Rotterdam niet van "hoge cultuur"-Minicollege van Koen van Eijck. http://vimeo.com/163417242

Van Oudenaarden, J., \& Vroegindeweij, R. (2015). Rotterdam. Rotterdam: Kick uitgevers.

Veldacademie (2017). Gesprek met de stad, een onderzoek naar het toekomstbeeld van bewoners van Rotterdam. Rotterdam: Veldacademie.

http://www.verhaalvandestad.nl

Williams, D. R. (2014). Making Sense of "Place": Reflections on Pluralism and Positionality in Place Research. Landscape and Urban Planning, 131, 74-82.

https://doi.org/10.1016/j.landurbplan.2014.08.002 